\title{
The Geography of Equity Listing and Financial Centre Competition in Mainland China and Hong Kong
}

\author{
Bas Karreman, and Bert van der Knaap
}

\begin{tabular}{|l|l|}
\hline \multicolumn{2}{|l|}{ ERIM REPORT SERIES RESEARCH IN MANAGEMENT } \\
\hline ERIM Report Series reference number & ERS-2010-033-ORG \\
\hline Publication & August 2010 \\
\hline Number of pages & 31 \\
\hline Persistent paper URL & http://hdl.handle.net/1765/20447 \\
\hline Email address corresponding author & karreman@ese.eur.nl \\
\hline Address & Erasmus Research Institute of Management (ERIM) \\
& RSM Erasmus University / Erasmus School of Economics \\
& Erasmus Universiteit Rotterdam \\
& P.O.Box 1738 \\
& 3000 DR Rotterdam, The Netherlands \\
& Phone: + 31 10 408 1182 \\
& Fax: + 31 10 408 9640 \\
& Email: info@erim.eur.nl \\
& Internet: www.erim.eur.nl \\
\hline
\end{tabular}

Bibliographic data and classifications of all the ERIM reports are also available on the ERIM website: www.erim.eur.nl 


\section{ERASMUS RESEARCH INSTITUTE OF MANAGEMENT}

\section{REPORT SERIES}

\section{RESEARCH IN MANAGEMENT}

\begin{tabular}{|c|c|}
\hline \multicolumn{2}{|c|}{ ABSTRACT AND KEYWORDS } \\
\hline Abstract & $\begin{array}{l}\text { This study examines the changing competitiveness of financial centres in mainland China and } \\
\text { Hong Kong based on the geography of equity listing of mainland Chinese firms. Pre-listing firm } \\
\text { characteristics are used to explore firms' motives for listing on a particular exchange and } \\
\text { whether these motives have changed over time. The results show that Hong Kong's prominence } \\
\text { as an international financial centre is attracting the largest and, recently, also the best performing } \\
\text { mainland Chinese state-owned enterprises to go public. Less differentiation exists between the } \\
\text { competitiveness of Shanghai and Shenzhen, although the renewed strategy of the Shenzhen } \\
\text { stock exchange to attract smaller firms appears to be successful. }\end{array}$ \\
\hline Free Keywords & financial centre competition, stock listing, Hong Kong, China \\
\hline Availability & $\begin{array}{l}\text { The ERIM Report Series is distributed through the following platforms: } \\
\text { Academic Repository at Erasmus University (DEAR), DEAR ERIM Series Portal } \\
\text { Social Science Research Network (SSRN), SSRN ERIM Series Webpage } \\
\text { Research Papers in Economics (REPEC), REPEC ERIM Series Webpage }\end{array}$ \\
\hline Classifications & $\begin{array}{l}\text { The electronic versions of the papers in the ERIM report Series contain bibliographic metadata } \\
\text { by the following classification systems: } \\
\text { Library of Congress Classification, (LCC) LCC Webpage } \\
\text { Journal of Economic Literature, (JEL), JEL Webpage } \\
\text { ACM Computing Classification System CCS Webpage } \\
\text { Inspec Classification scheme (ICS), ICS Webpage }\end{array}$ \\
\hline
\end{tabular}




\title{
The Geography of Equity Listing and Financial Centre Competition in Mainland China and Hong Kong
}

\author{
BAS KARREMAN $^{\ddagger}$ \\ BERT VAN DER KNAAP ${ }^{\S}$
}

This version: August, 2010

\begin{abstract}
This study examines the changing competitiveness of financial centres in mainland China and Hong Kong based on the geography of equity listing of mainland Chinese firms. Pre-listing firm characteristics are used to explore firms' motives for listing on a particular exchange and whether these motives have changed over time. The results show that Hong Kong's prominence as an international financial centre is attracting the largest and, recently, also the best performing mainland Chinese state-owned enterprises to go public. Less differentiation exists between the competitiveness of Shanghai and Shenzhen, although the renewed strategy of the Shenzhen stock exchange to attract smaller firms appears to be successful.
\end{abstract}

Key words: financial centre competition; stock listing; Hong Kong; China.

JEL Classification: G15; L10; R12; R38.

\footnotetext{
${ }^{\ddagger}$ Corresponding author: Erasmus University Rotterdam, ERIM. Erasmus School of Economics (H13-11), P.O. Box 1738, 3000 DR Rotterdam, The Netherlands. Tel: (+31) 10 4089579, Fax: (+31) 10 4089141. E-mail: karreman@ese.eur.nl

${ }^{\S}$ Erasmus University Rotterdam. E-mail: vanderknaap@ese.eur.nl
} 


\section{Introduction}

Ever since the stock markets in Shanghai underwent rapid growth in the late 1990s, there has been a debate in the popular press regarding whether Shanghai could overtake Hong Kong as China's pre-eminent international financial centre (e.g., Ng, 2000; Tao, 2009; Wild, 1997; Wong, 2007). Fuelled by China's rapid economic development and the increasing efforts of the central government to reform and liberalise the country's financial markets, this discussion has not lost any of its significance. Especially for Hong Kong, which largely derives its competitive advantage from providing mainland Chinese firms with unrestrained access to global capital (Enright et al., 1997; McGuiness, 1999; Meyer, 2002), the recent equity market developments in mainland China and the renewed focus on attracting foreign capital to Shanghai are exceptionally relevant. However, despite the economic significance of this debate, it is by no means clear to what extent equity market development and regulatory change impact the competitive positions of financial centres in mainland China and Hong Kong.

Extant research emphasises that these centres are developing as complements instead of competitors. The work by Zhao and colleagues underlines the functional complementarity of mainland Chinese financial centres based on analyses of the co-agglomeration of banks and (foreign) multinational firms (Zhao, 2003; Zhao et al., 2004; Wang et al., 2007). These findings are corroborated by Lai (2009), who clearly specifies that each financial centre has its own distinctive characteristics and advantages, identifying Beijing as a "political centre", Shanghai as a "business centre" and Hong Kong as an "offshore financial centre”. While they provide essential insights into the competitive advantages of each centre, these studies direct only limited attention to institutional and regulatory change and the dynamics of financial centre competition. In addition, the role of stock markets is under-emphasised, even though it was previously argued that stock markets are key building blocks of many financial centres (Thrift, 1994; Wójcik, 2009) and that financial centre competition is expected to be most intense in capital and securities markets (see Poon, 2003). Aside from a stock market study by Karreman and Van der Knaap (2009) showing that Shanghai, Shenzhen and Hong Kong have relatively distinct hinterlands and that these centres are rather complementary in terms of sectoral specialisation, little research has been done on this topic.

Therefore, the objectives of this paper are to examine the competitiveness of financial centres in mainland China and Hong Kong from a stock market perspective and to assess whether this competitiveness has changed over time. Following Pagano et al. (2001), stock 
markets compete on the basis of attracting more (foreign) listings than rival exchanges. As firms are generally confronted with various listing options, they are likely to choose the particular location that yields the most benefits relative to other alternatives. Hence, firms' decisions of where to list are a clear reflection of the competitive advantage of a financial centre. To test the degree of financial centre competitiveness, a sample of 1084 mainland Chinese firms that issued an initial public offering (IPO) of their shares on the Shanghai stock exchange (SSE), the Shenzhen stock exchange (SZSE) or the Hong Kong stock exchange (HKEX) in the period of 1993 - 2007 is used. The effectuation of the Securities Law (SL) on July 1, 1999, marks a clear distinction between two periods of stock market regulation and development. Anticipating the results, this study demonstrates that the determinants of listing choice between the SSE, SZSE and the HKEX differ between the pre- and post-SL periods. These differences are driven by significant changes in both financial and geographical attributes of mainland Chinese IPO firms. Overall, the results provide some preliminary evidence that firms in the post-SL period make more distinct listing choices, indicating that, relative to the pre-SL period, the financial centres in mainland China and Hong Kong have become more complementary over time. These findings provide important new insights into the less examined sub-national development process and the competitive dynamics of financial centres in mainland China and Hong Kong.

The remainder of this paper is organised as follows. The next section presents a theoretical background, discussing the factors that affect the geography of equity listing. Section 3 applies these insights to understand the listing decisions made by mainland Chinese firms and presents the hypotheses. Section 4 discusses the methodology and the data employed in the analysis, and section 5 presents the empirical results and their robustness. Finally, section 6 concludes with the main findings and some recommendations for further research.

\section{Background: the geography of equity listing}

As worldwide financial markets are by no means perfectly integrated and frictionless, it is generally known that the structure of the financial system in space and time matters for firms in search of external funds (Clark and Wójcik, 2003; Klagge and Martin, 2005). This continued significance of location is clearly evidenced in the literature on firms' listing decisions. Previous research has identified various motives for firms to enter public equity markets, including, inter alia, increased access to new capital (Ritter and Welch, 2002), 
enhanced credibility and visibility in the market (Bancel and Mittoo, 2009) and the creation of a market for existing shareholders to cash in some of their holdings (Roëll, 1996). However, the heterogeneity of financial markets across space means that not every domestic public equity market is equally beneficial to a firm's particular listing strategy. As a result, many firms decide to list abroad, bypassing their domestic exchanges entirely or by way of an additional (i.e., cross-) listing (see Bancel and Mittoo, 2001; Pagano et al., 2002; Karolyi, 2006).

For firms originating from emerging markets, a listing on a well-regulated and developed foreign exchange may be particularly attractive. Brennan and Subrahmanyam (1996), for instance, argue that the benefits of listing depend on the size and liquidity of the stock market. In liquid markets, individual transactions cause only minor price reactions, which can attract more trading volume and may result in a lower cost of capital for the firm. As stock markets in developing countries often have considerable liquidity problems, a foreign listing may thus be a viable option to overcome the inferiority of the domestic market. Furthermore, La Porta et al. (1998) underline the importance of the legal environment, whereby firms listed in a country with high standards of investor protection, strict disclosure requirements and an efficient bureaucracy may signal their overall quality and increase their attractiveness for investors. By subjecting themselves to more stringent listing requirements relative to their domestic market, emerging market firms listed abroad may enhance their information disclosure and transparency. In turn, this may be beneficial to their overall level of corporate governance (Stulz, 1999). As reviewed by Edison and Warnock (2008), the advantages of cross-listing for firms from emerging markets are multiple: lower informational and transaction costs for investors, more accurate analyst forecasts, more informative financial reporting and higher firm valuations. All of these factors should make the firm more attractive for investors and eventually improve its access to capital.

Although the characteristics of the host market largely determine the attractiveness of one listing location over another, the decision of where to list is also affected by proximity preference. Coval and Moskowitz (1999) show that investors are less willing to buy equities of firms with which they are not familiar, creating a geographically constrained "home bias at home”. A similar reasoning applies when explaining why economic, cultural and industrial proximity also play dominant roles in the decision of where to list (Sarkassian and Schill, 2003). Various types of proximity preferences are implicitly discussed in recent work by Wójcik and Burger (2010). In an exploratory study of the geographical patterns of international cross-listings by firms from Brazil, Russia, India and China (BRIC), these 
scholars underline the importance of industrial specialisation in the host market and the existence of trade links between the home and host markets as factors affecting the choice of listing destination. A novel result of the analysis is that firms from the leading financial centres of the BRIC countries are especially likely to list abroad. For mainland Chinese firms, comparable patterns are identified by Karreman and Van der Knaap (2009), who show that large internationally oriented mainland Chinese firms, mostly headquartered in Beijing, are more likely to list on the HKEX.

\section{Equity listing in mainland China and Hong Kong}

\subsection{Listing venue characteristics}

As a relative newcomer to the international financial market, mainland China constitutes an interesting case. In the traditional bank-based system, the partial privatisation of the large state-owned banks is beginning to erode the availability of cheap and easy credit and thus constrains the main source of capital for mainland Chinese firms (Zhang and King, 2010). As a result, the importance of stock markets and equity financing as an additional source of external finance is rapidly increasing. For example, four out of the world's fifteen largest IPOs were issued by firms from the mainland. Of these four, the Industrial \& Commercial Bank of China (ICBC) and the Agricultural Bank of China each raised approximately 19 billion US dollars in 2006 and 2010, respectively, the two largest IPOs ever. Yet, in contrast to the arguments of the general literature on the geography of equity listing, it is not straightforward for mainland Chinese firms to obtain a listing abroad. Due to severe capital account restrictions and exchange rate control, capital cannot flow freely between foreign locations and the mainland (Wang and Di Iorio, 2007). These constraints also affect Hong Kong, even though Hong Kong is under the same political sovereignty.

Despite the restrictions on the free flow of capital, Hong Kong has long been a major source of equity funds for mainland Chinese firms. Before the stock markets in Shanghai and Shenzhen commenced trading at the beginning of the 1990s, the Chinese government allowed selected companies to list in Hong Kong. For these firms, Hong Kong provided much needed access to foreign capital and a way to overcome the regulatory inferiority and the immaturity of the financial markets in mainland China (McGuiness, 1999). With well-developed and liquid financial markets, Hong Kong has proven itself an attractive location for mainland Chinese firms to issue stock. However, the current abundance of liquidity and recent financial market developments are making the domestic markets increasingly attractive and even 
encouraging companies initially listed in Hong Kong to dual list on the SSE or the SZSE (Chen, 2009). Given that the HKEX has long been a primary listing location for mainland Chinese firms, these developments might wear down the future competitive position of Hong Kong.

In this context, the IPO of ICBC is an informative example as ICBC was the first company to simultaneously list on the HKEX and the SSE, and the majority of the shares were issued in Shanghai. Given that preceding IPOs of the larger state-owned enterprises (SOEs) from mainland China were generally issued on the HKEX (Jia et al., 2005), the IPO of ICBC is illustrative of the changing competitive environment of the financial centres in mainland China and Hong Kong. The fact that the IPO was distributed over two exchanges underlines that the markets in the mainland and Hong Kong are not yet integrated (Wang and Di Iorio, 2007). Key factors maintaining these sub-national spaces are institutional and regulatory heterogeneity as well as considerable differences between the business environments in the two locations. To understand how these factors affect the listing decisions made by mainland Chinese firms, it is important to have a clear understanding of the market structure of the mainland Chinese and Hong Kong exchanges.

\subsubsection{Market structure of mainland Chinese exchanges}

Mainland Chinese firms are able to issue two types of stock, namely A-shares and B-shares, where A-shares are designed for domestic Chinese investors and traded in domestic currency while B-shares are denominated in foreign currency for foreign investors. Although the Aand B-share markets are segmented, recent share reforms and regulatory developments have relaxed the strictness of this division. For instance, since 2001, the B-share market has been open to domestic investors, while the introduction of the Qualified Foreign Institutional Investment (QFII) measures in 2002 allows selected authorised foreign institutional investors to participate in the A-share market (Yeo, 2003). Although an IPO on the B-share market of the SSE or the SZSE is formally still possible, no new B-shares have been listed since 2001. Therefore, with the decreased necessity of market segmentation, it is doubtful whether there is a reason for the B-share market to continue to exist (Hovey and Naughton, 2007).

The mainboards of the SSE and the SZSE are dominated by large and partially privatised SOEs, with limited access for smaller and medium-sized enterprises (SMEs) and privately owned firms (Chen, 2009). As a result, most of the listed shares on each exchange are nontradable and state-owned. For example, at year-end 2008, only 37.3 percent of the total market capitalisation of the SSE and SZSE combined represented tradable market capitalisation 
(CSRC, 2010). In order to overcome some of the problems of limited access to the exchanges and thus the insufficient functioning of these markets, the SZSE launched the SME board in 2004. Although the number of firms listed grew quite rapidly to 273 at year-end 2008 (CSRC, 2010), the SME board is still underdeveloped and characterised by a small market capitalisation and a rather narrow industry coverage (Chen, 2009). In addition, the introduction of a NASDAQ-like growth enterprise market (GEM) for small high-tech firms in Shenzhen was finally realised in 2009.

\subsubsection{Mainland Chinese firms on the HKEX}

There are two ways for a mainland Chinese firm to obtain a listing on the HKEX, either through a "red-chip" or an H-share. The main difference between the two share types is their locational incorporation. Red-chips are companies incorporated in Hong Kong but controlled from the mainland, while $\mathrm{H}$-shares correspond to listings of firms incorporated in mainland China. Both share types are traded on the HKEX and denominated in Hong Kong dollars.

In terms of share ownership, these firms are predominantly owned by state, provincial and municipal authorities (McGuiness, 1999). The mainland Chinese firms listed in Hong Kong are among the largest in the country and are therefore of major importance for the HKEX. In terms of market capitalisation, the combination of $110 \mathrm{H}$-share and 89 red-chip listings accounted for 54.5 percent of the total market capitalisation of the HKEX at year-end 2008. This is an enormous share of total market capitalisation when taking into consideration that the number of other firms listed on the HKEX at year-end 2008 was 1,062 (HKEX, 2009). Moreover, the HKEX operates a growth enterprise market for small-capitalised high-tech firms that has also been accessible for mainland Chinese firms since 1999.

\subsection{Listing behaviour of mainland Chinese firms}

Although mainland Chinese firms that are listed on the SSE, SZSE or HKEX are relatively large and often only partially privatised, it is by no means clear which firms will choose to list where and why. For instance, why is China Mobile listed in Hong Kong, while Baoshan Iron \& Steel Company is listed in Shanghai? Based on the outcomes of previous research, ex ante financial as well as geographical attributes of these firms are examined to provide an indication of the listing choices particular firms make. Following Pagano et al. (2002) and Zhang and King (2010), these ex ante predictors are used to explore the motives of listing on a particular stock exchange. As these motives are, in turn, determined by stock market, 
institutional and regulatory characteristics and financial centre location, they provide means by which to distinguish the competitive advantages of each financial centre.

\subsubsection{Financial attributes}

The sophistication and liquidity of the financial markets in Hong Kong are the main motives for mainland Chinese firms to choose the HKEX as their location for IPO issuance over the SSE or the SZSE. Allen et al. (2005) demonstrate and argue that, relative to Hong Kong (and many countries in the world), the legal system and the financial markets in mainland China are still highly underdeveloped in terms of investor protection systems, corporate governance, accounting standards and the overall quality of the government. In addition, Chen (2009) suggests that the rules and regulations governing the mainland Chinese capital markets may already be sufficiently developed, identifying the lack of enforcement as the real problem. For mainland Chinese firms, the low costs of audit failure and the fact that equity finance often represents only a minor part of their total capital structure reduces the incentives for managers to invest in information disclosure and corporate transparency (Ferguson and McGuiness, 2004). As a result, there are many examples of listed firms that were involved in price manipulations, fake transactions, and deliberate provision of incorrect information to investors (Green, 2004).

Mainland Chinese firms that are able to comply with the strict requirements and the close scrutiny of foreign investors and regulatory authorities of the HKEX are more likely to signal their quality and performance as well as their corporate transparency and trustworthiness (Liu and Eddy, 2007). However, it is not easy to list on the HKEX as the costs of listing outside the mainland are relatively high (Zhang and King, 2010). Several explanations exist for these high costs. First, in terms of accounting systems, an H-share (or red-chip) issue requires firms to comply with international financial reporting standards (IFRS), while for an A-share listing on the SSE or the SZSE, domestic accounting standards are sufficient. Adopting IFRS is a complex and expensive procedure that is easier to accomplish for larger state-owned firms. Second, the HKEX has more stringent listing requirements on market capitalisation and a higher cost of listing than the SSE or the SZSE. In particular, the listing fees and additional administrative costs of listing in a different institutional environment are considerable. Again, these costs are more manageable for large SOEs. Besides, a listing in Hong Kong with foreign shareholders makes the firm more politically and internationally visible and subject to more public scrutiny. Mainland Chinese firms that want to signal their quality and performance are likely to welcome a closer monitoring of regulatory agencies and may voluntarily disclose and 
disseminate more information about the firm (Liu and Eddy, 2007). Firms that are relatively profitable are more likely to do so. Taking these arguments together, in terms of financial attributes, it can be expected that larger, state-owned and relatively profitable mainland Chinese firms are better able to overcome the inherent difficulties of listing in Hong Kong and are thus more likely to choose to go public on the HKEX versus the SSE or the SZSE.

\subsubsection{Geographical attributes}

Besides financial attributes, it is well-known that geography is a major determinant of firms' listing decisions. Especially in mainland China, where relatively low levels of corporate governance practices and financial reporting standards combined with a large presence of individual investors cause persistent information asymmetries (Bailey et al., 2009), proximity may be an important factor affecting access to relevant information and, thus, may enhance the attractiveness of a firm's stocks. As showed by Karreman and Van der Knaap (2009), the SSE and the SZSE have an overrepresentation of listed firms from nearby provinces, whereas the HKEX is dominated by firms originating from Beijing. This indicates that proximity preference may indeed be an important consideration for firms to list on the SSE and the SZSE, while it may be less important for listing on the HKEX. Therefore, it can be expected that firms that are headquartered geographically proximate to Shanghai or Shenzhen are also more likely to list on, correspondingly, the SSE or the SZSE relative to the HKEX. In addition, it can be expected that mainland Chinese firms located in the Shanghai region and the Shenzhen region reveal a strong "home bias at home" for the SSE and the SZSE, respectively, while firms located in the region of Beijing are more likely to choose a listing on the HKEX.

\subsubsection{Stock market development and changes in listing decisions over time}

Since the opening of the markets in Shanghai and Shenzhen, the stages of equity market development in mainland China can roughly be subdivided into an expansion stage from 1992 to 1998 and the (current stage of) systematic development and regulation that commenced with the enactment of the SL in 1999 (Chen, 2009). Obviously, the two stages are likely to differ in terms of listing options and procedures and the listing choices made by mainland Chinese firms. Two main events are discussed: first, the development of the equity market structure and, second, the corresponding regulatory reform. An important issue in these discussions is the changing relevance of the China Securities Regulatory Commission 
(CSRC), which developed from a civil agency with no authority supervising securities firms into a powerful governmental institution controlling all security-related affairs (Green, 2004).

In the pre-SL period, the SSE and the SZSE functioned as two independent exchanges with a similar focus: rapid development. With the limited power of the CSRC, most of the major approvals during the listing application process took place at the local level. According to Green (2004: p.92), this period unfolded as a true "war of the exchanges” for listings, with no clear policy on attracting particular types of firms. The post-SL period has witnessed considerable change in this regard. The CSRC has become the main authority in charge of the listing process, such that a decision on the approval or denial of listing made by the CSRC cannot be opposed. In addition, the rapidly expanding SME board and the recently launched Shenzhen GEM have reconfigured the competitive focus of the SZSE relative to the SSE towards the attraction of smaller high-technology firms. Therefore, it can be expected that, relative to the pre-SL period, smaller-sized and technology-oriented firms are more likely to choose a listing on the SZSE relative to the SSE or the HKEX in the post-SL period.

Based on the characteristics of the current, that is, the post-SL listing process, it has previously been argued that, in terms of financial attributes, larger and relatively profitable mainland Chinese SOEs are better able to overcome the inherent difficulties of going public in Hong Kong. However, in the pre-SL period this was not necessarily the case. Especially between 1992 and 1997, the process of obtaining a listing in Shanghai, Shenzhen or Hong Kong was rather ambiguous (Green, 2004). Firms that struggled through the provincial bureaucracy and finally obtained approval from the CSRC could apply for a listing on the stock exchange of their choice. However, at that time the CSRC was only a non-governmental organisation and could hardly reject applications that were personally sponsored by highranked governmental individuals. As a result, the quality and performance of the SOEs coming to market was generally poor. According to Jia et al. (2005), similar arguments applied for the H-share listing process, whereby the firms selected to list in Hong Kong were relatively large and state-owned but not necessarily the best performers. This argument contrasts the previously discussed motive of mainland Chinese firms to preferentially choose a listing in Hong Kong over one on the SSE or the SZSE to signal their quality and performance.

Furthermore, increased specialisation of the exchanges in the post-SL period may reduce the proximity preference of firms. As firms prefer to list on the same exchange as their peers (Pagano et al., 2001), specialisation of stock exchanges may initiate imitation effects for firms in their decisions of where to list. When taking into account that firms that are not capable of 
becoming listed with their peers may face competitive disadvantages (Stoughton et al., 2001), specialisation is likely to overcome the proximity preference of listing. Therefore, in terms of geographical attributes, proximity preference is expected to be higher in the pre-SL period compared to the post-SL period.

In conclusion, it is reasonable to expect that the attributes that determine the listing choice of mainland Chinese firms differ considerably between the pre-SL and the post-SL period.

\section{Data and methodology}

\subsection{Data and sample characteristics}

The initial sample was collected from Thomson Datastream and includes all IPOs of mainland Chinese firms issued on one of the mainland Chinese exchanges in Shanghai or Shenzhen or on the Hong Kong stock exchange from 1973 to 2007. For Shanghai and Shenzhen, both Aand B-share IPOs are included, while for Hong Kong H-shares and red-chips are considered as two possible options for IPO issuance. The date of initial listing is assumed to be the first day on which Datastream reports financial information about the firm. Balance sheet data on the characteristics of the firm come from Worldscope. As the focus is on the listing choices of firms when they go public, only those IPO firms that actually had a choice between trading on the SSE, SZSE or the HKEX are included in the dataset (c.f. Corwin and Harris, 2001). For that reason, the initial sample is restricted by four factors: time and IPO suspension, overlap, minimum listing requirements, and data availability.

Tsingtao Brewery was the first firm to list on the HKEX via the offer of H-shares in July 1993. This event marks the date on which mainland Chinese firms became able to formally list in Hong Kong. Therefore, the sample is restricted to those IPOs issued between July 1993 and December 2007. In addition, the markets in Shanghai and Shenzhen were each temporarily closed for new IPOs during certain time periods. For the SZSE, the CSRC imposed a suspension from October 2000 to January 2004 to explore the possibilities of a merger with the SSE and the introduction of the Shenzhen GEM (Green, 2004). For the SSE, an IPO suspension period was imposed from April 2005 to May 2006, mainly to convert state-owned equity into tradable shares (Chen, 2009). Both closures were the direct result of necessary reforms and fundamental changes in the Chinese equity markets. As both periods were characterised by a reduced number of listing venue choices, IPOs issued in these periods on one of the remaining exchanges were removed from the sample. 
Second, to avoid overlap in the data, only the initial IPO is included in the sample. Subsequent issues or cross-listings by the same firm on other exchanges are excluded. Additional listings may occur in two ways: within a particular stock market or between stock markets. For instance, a firm may decide to initially issue B-shares and subsequently A-shares on the same exchange. Moreover, there are many examples of mainland Chinese firms with an H-share IPO that later opt for an additional A-share listing on the SSE or SZSE. In these cases, only the first issuance of shares to the public was considered. Note that regulations do not permit B- and H-share combinations. Four firms that simultaneously issued A-shares on one of the mainland Chinese markets and H-shares in Hong Kong. These issuers are included in the Hong Kong sample because the effort required to obtain a listing in Hong Kong relative to that required for the SSE or SZSE signals that the main purpose of the IPO was to issue Hshares (see Zhang and King, 2010).

Third, the sample includes only those firms that meet the minimum listing requirements of the HKEX as these are the most restrictive across the three exchanges. Because the primary interest of this study is to understand the choice of listing venue, only firms that could formally list on all three exchanges are included in the sample. Of the current HKEX requirements, two issues stand out: the profit test and market capitalisation requirements. Because the CSRC demands higher profits for firms that want to list on the SSE or the SZSE than the HKEX does, the profit test will be met by Chinese issuers. However, following the profit test, the market capitalisation requirements on the HKEX are higher compared to the mainland Chinese exchanges. Therefore, to be included in the sample, a firm has to have a market capitalisation of at least HK 200 million dollars (HKEX, 2010).

\section{[Table 1 about here]}

Finally, the size of the sample is constrained by data availability; in particular, it is impossible to track the precise locations of some firms' headquarters in mainland China, and in other cases firm specific data are not, or are not fully, available at the time of the IPO. Table 1 provides the characteristics of the total sample of IPO firms used in the analysis, in which Panel A shows the frequency of IPOs by exchange per year and Panel B displays the number of IPOs per industry. Three notable issues can be derived from Table 1. First, the years 2001 to 2003 are not included due to the closures of the SSE and the SZSE to new IPOs. Second, the restrictive policies on IPO issuance in 1995 and 2005 resulted in relatively low IPO frequencies for these particular years. Finally, it is apparent that the stock markets in 
mainland China and Hong Kong have a predominant focus on basic materials, consumer goods and industrials.

\subsection{Regulatory change and sub-samples}

The introduction of the SL marked a major step forward in the development of an improved regulatory framework governing the listing of shares on the mainland Chinese stock exchanges. As this change may have altered the attractiveness of listing on the SSE and SZSE relative to the HKEX, the implementation of the SL on July 1, 1999, demarcates two separate periods of stock market development. The differences between the two periods are examined by splitting the sample into two subsamples: one that captures the 1993 to July 1999 period and one representing the period after the SL implementation from July 1999 until December 2007. Similar to the total sample, the subsamples only include mainland Chinese firms that meet the market capitalisation restrictions of the HKEX.

\subsection{Methodology: models of financial centre choice}

To explain the relation between the choice of listing venue and the attributes of mainland Chinese IPO firms, it is assumed that mainland Chinese firms will choose to issue an IPO in the location where they maximise benefit. This points to two appropriate models: multinomial logit (MNL) and multinomial probit (MNP).

The main difference between these two models is that, in contrast to MNP, the MNL model imposes the assumption of "independence from irrelevant alternatives" (IIA). This assumption states that the choices across alternatives have to be independent. In this context, it can be argued that the choice between listing in Shanghai or in Shenzhen is not independent because these exchanges are subject to the same institutional and regulatory environment. Thus, the violation of the IIA assumption favours MNP over MNL. However, the disadvantages of estimating a MNP model should also be considered when choosing the most suitable model. For instance, the computational difficulties in estimating MNP may yield imprecise parameter estimates, affecting statistical inferences.

As the IIA is a logical property of decision making and not a statistical one, like consistency or unbiasedness, the imposition of the IIA assumption in applied research is often overestimated (Dow and Endersby, 2004). Therefore, MNL is used in the baseline regressions. In addition, to check for the potential impact of IIA violation on the results, MNP estimation is used as a robustness check. 


\subsection{The choice of listing venue}

The dependent variable explained in the models is a mainland Chinese firm's decision regarding where to list its shares, that is, the choice between issuing an IPO on the stock exchange of Shanghai, Shenzhen or Hong Kong. This decision of where to list is explained by the cross-sectional differences in balance sheet and additional firm-specific characteristics between the mainland Chinese firms in the sample.

\subsubsection{Financial attributes}

Prior research has underlined the potential importance of particular balance sheet variables in the choice of listing venue (Corwin and Harris, 2001; Pagano et al., 2002). However, as previously argued, some of these variables may have particular meanings in the context of mainland Chinese firms.

Firm size is measured by the total assets of the mainland Chinese firm reported at yearend prior to the year of IPO issuance. The nominal values of the total assets are deflated and taken in logs to facilitate meaningful comparison. Although other measures are also applied in the literature to proxy firm size, such as the total number of employees or the market value of common stock, total assets are widely used in predicting the location choices of firms in search of a (foreign) listing (Pagano et al., 2002; Zhang and King, 2010).

As a performance indicator, the return on assets (ROA) is used. ROA is defined as the total operating income divided by the total assets of the mainland Chinese firm prior to the IPO. Sales to assets is also used quite often, but it has the disadvantage that many service firms do not report sales. As such, using a measure that depends to some extent on sales may exclude particular industries (i.e., services industries) from the sample.

Because it is difficult to measure precisely the degree of state control of each mainland Chinese IPO firm, block ownership is used as a proxy. An IPO firm has a block owner when a single institution controls at least 50 percent of its shares. On average, most of the shares of mainland Chinese firms that opt for a listing are state-owned (see Allen et al., 2005). These shares are often distributed among several other legal persons, such as municipalities or other listed or non-listed firms, in a cross-shareholding structure. However, strategically important SOEs are likely to be majority owned by a single governmental institution in order to facilitate optimal corporate control. Block ownership is a dummy variable that takes the value 1 when a single institution controls at least 50 percent of the shares and 0 otherwise. 


\subsubsection{Geographical attributes}

To account for the effects of proximity preference on the choice of listing venue, two geographical attributes are included. The first is the (log of) geographical distance between the location of the headquarters of the listed companies and their respective stock exchanges. Although this can be calculated relatively easily for A-, B-, and H-shares by tracking the firms' zip codes, for the red-chips this identification is more demanding. As the registered headquarters of a red-chip firm are in Hong Kong, the controlling mainland Chinese shareholder has to be identified by unravelling each firm's shareholder structure. The zip code of this majority shareholder is used to calculate the geographical distance between the redchip controlling firm and the HKEX. Second, dummy variables are included for Beijing, Shanghai and Shenzhen to control for the overrepresentation of firms from the home province of each exchange, whereby Beijing is considered to be the home province of the HKEX (c.f. Karreman and Van der Knaap, 2009). As Shenzhen is only a county in Guangdong province and both Beijing and Shanghai are city provinces, Shenzhen is represented by the cities located in the Pearl River Delta economic zone in order to capture overrepresentation correctly and to facilitate comparison. ${ }^{1}$

\subsubsection{Additional controls}

To control for the potential influence of imitation effects among firms active in similar industries (see Pagano et al., 2001), industry dummies based on the Industry Classification Benchmark (ICB) are included in the model. This is of particular importance in the case of listing choice between the stock markets in mainland China and Hong Kong as previous research has demonstrated that these markets exhibit sectoral complementarity (Karreman and Van der Knaap, 2009). Finally, year dummies are added to the model to control for a priori differences between the years in which the IPOs were issued.

\section{[Table 2 about here]}

Table 2 shows the Pearson's correlations and the descriptive statistics of the dependent and explanatory variables. A notable aspect of Table 2 is that the Shanghai and Shenzhen dummies to control for the overrepresentation of firms from the home province of each exchange display a rather high negative correlation with geographical distance, which

\footnotetext{
${ }^{1}$ Following Enright et al. (2005), the Pearl River Delta economic zone includes: Shenzhen, Guangzhou, Dongguan, Foshan, Zhongshan, Zhuhai and Jiangmen.
} 
indicates the possible existence of a regional home bias. However, these discussed correlations are not expected to inflict collinearity problems.

\section{Results: Determinants of listing venue choice}

\subsection{Results of the baseline models}

Table 3 shows the results of the MNL estimation whereby the SSE functions as a base alternative. It is important to note that the estimated coefficients in Table 3 are not marginal effects like in ordinary least squares models, but represent the effect of a change in each independent variable on the probability of selecting either of the other two exchanges relative to the probability of choosing the SSE.

\section{[Table 3 about here]}

Model 1 of Table 3 shows the MNL estimates for the total sample and yields some interesting results. First, in terms of total assets, large IPO firms are significantly more likely to choose a listing on the HKEX than a listing on the SSE but are significantly less likely to choose a listing on the SZSE relative to the SSE. This result is in line with expectations and clearly demonstrates a relative distinction between the three exchanges in terms of the attractiveness of firms of particular sizes. Second, the significant positive coefficient of ROA suggests that high performing firms are more likely to list on the HKEX relative to the SSE. This finding is consistent with the argument that firms choose to list in Hong Kong to signal their quality and performance. Zhang and King (2010) report similar findings. Third, when considering the geographical distance of the headquarters of the IPO firm to the exchange of listing, the coefficients show that firms that are located further away from one of the exchanges have a significantly higher likelihood of choosing the SZSE or the HKEX as listing venues relative to the SSE. Finally, the results reveal a considerable "home bias at home" for firms originating from Beijing and Shenzhen. For instance, relative to the SSE, firms from Beijing are significantly more likely to list on the HKEX and significantly less likely to list on the SZSE. Additionally, Shenzhen-based firms have a significantly higher likelihood of listing on the SZSE (and the HKEX) versus the SSE.

Models 2 and 3 in Table 3 show the MNL estimates for the pre-SL and the post-SL periods respectively. There are notable differences in both financial and geographical attributes across the two time periods. First, larger firms are significantly less likely to list on 
the SZSE versus the SSE in the post-SL period, while in the pre-SL period this difference between the SZSE and SSE is not significant. This result indicates that in the post-SL period, smaller firms prefer to list on the SZSE relative to the SSE, which is consistent with the expectations that the transformation of the equity market structure in Shenzhen results in the attraction of smaller-sized firms. Second, the positive and significant coefficient of ROA for the HKEX in Model 3 indicates that, in the post-SL period, high-performing firms are significantly more likely to issue an IPO on the HKEX than on the SSE or the SZSE. As expected, this significant and positive coefficient of ROA is not present in the pre-SL period in Model 2. Third, the positive and significant coefficient of block is consistent with the expectation that majority-owned SOEs are more likely to list on the HKEX relative to the SSE and the SZSE, but in the post-SL period only. Fourth, in terms of geographical attributes, the pre-SL period shows that firms headquartered in Beijing and Shanghai are significantly less likely to list on the SZSE relative to the SSE. In contrast, this is not the case in the post-SL period. This finding is noteworthy as it indicates that, in the post-SL period, proximity preference has become less important for the decision of where to issue an IPO. In addition, while Shenzhen-based firms are significantly more likely to choose the HKEX over the SSE in the pre-SL period, no such relationship is observed in the post-SL period.

\section{[Table 4 about here]}

An additional finding is the variation in the joint significance of the industry dummies between the pre- and post-SL periods in Models 2 and 3 of Table 3. To explain this difference, the individual coefficients of the industry dummies are presented in Table 4. To start with, Model 4 shows that the Industrials, Oil \& Gas and Technology coefficients for the HKEX are positive and significant, implying that, compared to Basic Materials, these firms are significantly more likely to choose to list on the HKEX relative to the SSE. These findings are similar to the results of Karreman and Van der Knaap (2009). Yet, in Models 5 and 6 of Table 4, the positive and significant effects of Industrials and Oil \& Gas for the HKEX are largely driven by the listing decisions in the pre-SL period, while Technology firms make more explicit decisions regarding where to list in the post-SL period. While contrary to the expectation that technology-oriented firms prefer to list on the SZSE in the post-SL period, these finding are consistent with previous research stating that high-growth, capital-intensive firms have a higher propensity to list abroad than those from stable sectors like consumer goods (Wójcik and Burger, 2010). Finally, it is noteworthy that the post-SL year dummies 
become highly significant due to the unstable distribution of IPO frequencies between the SSE, SZSE and HKEX (see also Table 1, Panel A). Additionally, the model fit of Model 3 is considerably better than those of Models 1 and 2.

In sum, a likelihood ratio (LR) test for joint significance, stating that all coefficients of Model 1 do not vary between the disjointed subsets of the data in Models 2 and 3 of Table 3, indicates that the differences in the determinants of the listing choices of mainland Chinese firms between the pre- and post-SL periods are highly significant $\left(\operatorname{LR} \chi^{2}(32)=72.55, p<0.001\right)$.

\subsection{Marginal effects}

Because the coefficient estimates in Table 3 represent the effects of the independent variables on the relative probabilities of choices, it is difficult to make meaningful comparisons of the absolute values of the coefficients across the different exchanges. To overcome this problem and to determine the direct (instead of the relative) effects of the independent variables on the listing choices of mainland Chinese firms, marginal effects can be estimated. These marginal effects are listed in Table 5.

\section{[Table 5 about here]}

The results are generally consistent with the findings in Table 3. However, some differences exist in Model 9 of Table 5. For instance, block is no longer significant, indicating that the initial finding of a significant effect of block in Model 3 of Table 3 is rather weak. Another difference is that, in the post-SL period, firms headquartered in Beijing are no longer significantly more likely to choose a listing in Hong Kong. A possible cause of these differences is the relatively small number of observations from Beijing-based firms in the HKEX sample. In addition, note that, while they are significant, the marginal effects of ROA on the decision of where to list are very small. Overall, Table 5 provides a more easily interpretable indication of the impacts of the individual variables on the choice of listing. For instance, Model 4 shows that firms headquartered in the Shenzhen region have a 36 percent higher probability of choosing to list on the SZSE than on the SSE.

\subsection{Robustness}

To make sure that the results are robust, two additional methodological checks are performed. First, as already announced in the methodology section, the model is re-estimated by MNP estimation to check for the potential importance of the IIA property's affecting the MNL 
estimates. The results of MNP estimation in Table 6 (see appendix) lead to similar conclusions as the MNL outcomes in Table 3, indicating that IIA is not a severe problem in this particular case. Second, because the primary equity markets in mainland China and Hong Kong include some extremely large IPOs, the sample contains non-erroneous outliers on both the SSE and HKEX. To examine the possible effects of these outliers on the predicted choice probabilities in the baseline models, an outlier analysis is performed. Although the determination of outliers is rather arbitrary, an often applied method is to exclude all cases that are larger than the mean plus two times the standard deviation of the variable of interest. For this study, extreme values are selected based on an extremely large IPO in terms of total assets of the underlying firm. This method yielded 16 outliers representing the largest and most well-known mainland Chinese firms, such as SinoPec, Air China and China Mobile. Most of these extremely large IPOs (11) were issued on the HKEX. The results in Table 7 (see appendix) show that the baseline regressions in Table 3 are robust to outliers as the findings from both models yield similar conclusions. One interesting difference however, is that the industry imitation effect for the HKEX relative to the SSE and the SZSE becomes persistent across the pre- and post-SL periods.

\section{Conclusion: towards specialisation and complementarity?}

The current literature on financial centre competition is uniform in its conclusion that the financial centres in mainland China and Hong Kong have become relative complements over time. Although financial centre competition is expected to be most intense in capital and securities markets, these conclusions are primarily based on insights from the banking sector. This leaves the question of whether this complementarity issue also holds for financial centre rivalry from a stock market perspective. While previous research shows that these centres have relatively distinct hinterlands and that they are sectorally specialised, there is little, if any, knowledge on how and why these financial centres, and the stock markets therein, developed as relative complements over time. This study attempts to shed some light on this issue by unravelling the competitive advantages of Shanghai, Shenzhen and Hong Kong as financial centres based on the decisions of mainland Chinese firms of where to list. To examine how these advantages have developed over time, a distinction is made between two periods of stock market development: a pre- and a post-SL period. The main findings are twofold. 
First, the results show that, in terms of financial attributes, mainland Chinese firms make more distinct listing choices in the post-SL period compared to the pre-SL period. For the preSL period, the only finding is that larger firms are more likely to list in Hong Kong. In contrast, for the post-SL period, it can be concluded that larger and more profitable (majority owned) firms prefer to list on the HKEX over the SSE and the SZSE. Although obtained in a limited setting, this outcome is consistent with the Chinese public's concern that the largest and best performing SOEs from the mainland are currently listing abroad (see Lai, 2009). Besides, in the post-SL period, smaller mainland Chinese firms are more likely to list on the SZSE, which is in line with the recent strategy of the CSRC to redevelop the SZSE into an exchange focused on SMEs.

Second, in terms of geographical attributes, there has been a change from explicit locational preferences of Beijing-, Shanghai- and Shenzhen-based firms in the pre-SL period towards a less predetermined geographical pattern in the post-SL period. The only exceptions are firms headquartered in the Shenzhen region, which display a persistent home bias in both periods. The finding that geographical distance remains important has two implications. On the one hand, it may signal improved corporate governance of Beijing- and Shanghai-based firms in terms of information disclosure, decreasing the information asymmetry problem. On the other hand, and in line with the previous argument, when these firms are more informationally transparent, they are less location bound. This alleviates the need to decide where to list and enhances the probability that these firms will list where they prefer to be listed: on the same exchange as their peers.

Overall, the findings show that geographical attributes have become less influential in choosing the exchange on which to offer an IPO, while financial characteristics of IPO firms have become more important. This shift implies increasing segregation of firms in their listing choices, indicating that the financial centres of mainland China and Hong Kong are becoming more specialised. Hong Kong's prominence as a well-developed international financial centre is currently attracting the best and largest mainland Chinese SOEs. While there is less differentiation in attractiveness between Shenzhen and Shanghai, Shenzhen has clearly refocused its strategy towards SMEs. As Lai (2009) rightfully argues, this strengthens the possibilities for specialised collaborative efforts, whereby functional coordination may enhance the competitiveness of each financial centre (Shi and Hamnett, 2002). This finding also underlines the fact that new research should be directed towards understanding how the interplay between competition and cooperation shapes the success of the financial centres in mainland China and Hong Kong. 


\section{References}

Allen, F., Qian, J. and Qian, M. (2005) Law, finance, and economic growth in China. Journal of Financial Economics, 77: 57-116.

Bailey, W., Cai, J., Cheung, Y.L. and Wang, F. (2009) Stock returns, order imbalances, and commonality: Evidence on individual, institutional, and proprietary investors in China. Journal of Banking and Finance, 33: 9-19.

Bancel, F. and Mittoo, U.R. (2001) European managerial perceptions of the net benefits of foreign stock listings. European Financial Management, 7: 213-236.

Bancel, F. and Mitto, U.R. (2009) Why do European firms go public? European Financial Management, 15: 844-884.

Brennan, M.J. and Subrahmanyam, A. (1996) Market microstructure and asset pricing: On the compensation for illiquidity in stock returns. Journal of Financial Economics, 41: 441-464.

Chen, C-H. (2009) An update on China's capital markets: focus on China's securities industry. In J.R. Barth, J.A. Tatom, G. Yago (eds) China's Emerging Financial Markets: Challenges and Opportunities, pp. 547-580. New York: Springer.

Clark, G.L. and Wójcik, D. (2003) An economic geography of global finance: Ownership concentration and stock-price volatility in German firms and regions. Annals of the Association of American Geographers, 93: 909-924.

Corwin, S.A. and Harris, J.H. (2001) The initial listing decisions of firms that go public. Financial Management, 30: 35-55.

Coval, J.D. and Moskowitz, T.J. (1999) Home bias at home: Local equity preference in domestic portfolios. Journal of Finance, 54: 2045-2073.

CSRC (2010) Securities market data. http://www.csrc.gov.cn/pub/csrc_en/marketdata [accessed July 2010].

Dow, J.K. and Endersby, J.W. (2004) Multinomial probit and multinomial logit: A comparison of choice models for voting research. Electoral Studies, 23: 107-122.

Edison, H.J. and Warnock, F.E. (2008) Cross-border listings, capital controls, and equity flows to emerging markets. Journal of International Money and Finance, 27: 1013-1027.

Enright, M.J., Scott, E.E. and Dodwell, D. (1997) The Hong Kong Advantage. Hong Kong: Oxford University Press.

Enright, M.J., Scott, E.E. and Chang, K-M. (2005) Regional Powerhouse: The Greater Pearl River Delta and the rise of China. Singapore: John Wiley \& Sons. 
Ferguson, M.J. and McGuiness, P.B. (2004) Chinese securities reform: The role of QFIIs in the corporate governance process. Business Horizons, 47: 53-61.

Green, S. (2004) The Development of China's Stock Market: Equity Politics and Market Institutions. London: Routledge Curzon.

HKEX (2009) Hong Kong Stock Exchange Factbook 2008. Hong Kong: HKEX.

HKEX (2010) Rules governing the listing of securities on the stock exchange of Hong Kong Ltd. Hong Kong: HKEX.

Hovey, M. and Naughton, T. (2007) A survey of enterprise reforms in China: The way forward. Economic Systems, 31: 138-156.

Jia, J., Sun, Q. and Tong, W.H.S. (2005) Privatization through and overseas listing: Evidence from China's H-share firms. Financial Management, 34: 5-30.

Karolyi, G.A. (2006) The world of cross-listings and cross-listings of the world: Challenging conventional wisdom. Review of Finance, 10: 99-152.

Karreman, B. and Van der Knaap B. (2009) The financial centres of Shanghai and Hong Kong: Competition or complementarity? Environment and Planning A, 41: 345-367.

Klagge, B. and Martin, R.L (2005) Decentralized versus centralized financial systems: Is there a case for local capital markets? Journal of Economic Geography, 5: 387-421.

La Porta, R. Lopez-de-Silanez, F., Shleifer, A. and Vishny, R. (1998) Law and finance. Journal of Political Economy, 106: 1113-1155.

Lai, K.P.Y. (2009) Global cities in competition? A qualitative analysis of Shanghai, Beijing and Hong Kong as financial centres. GAWC Research Bulletin, 313. http://Www. lboro.ac.uk/gawc/rb/rb313.html [accessed July 2010]

Liu, J. and Eddy, I.A. (2007) Determinants of disclosures of A-, B- and H-share companies. Asian Review of Accounting, 15: 72-92.

McGuiness, P.B. (1999) A Guide to the Equity Markets of Hong Kong. New York: Oxford University Press.

Meyer, D.R. (2002) Hong Kong: Global capital exchange. In S. Sassen (ed) Global Networks, Linked Cities, pp. 249-272. New York: Routledge.

Ng, I. (2000) A clash of two cities. Time (Asia), 156 (December 11): 24-26.

Pagano, M., Randl, O., Roëll, A.A., Zechner, J. (2001) What makes stock exchanges succeed? Evidence from cross-listing decisions. European Economic Review, 45: 770-782.

Pagano, M, Roëll, A.A, Zechner, J. (2002) The geography of equity listing: Why do companies list abroad? Journal of Finance, 57: 2651 - 2694. 
Poon, J.P.H. (2003) Hierarchical tendencies of capital markets among international financial centres. Growth and Change, 34: 135-156.

Ritter, J.R and Welch, I. (2002) A review of IPO activity, pricing, and allocations. Journal of Finance, 57: 1795-1828.

Roëll, A. (1996) The decision to go public: An overview. European Economic Review, 40: 1071-1081.

Sarkassian, S. and Schill, M.J. (2004) The overseas listing decision: New evidence of proximity preference. Review of Financial Studies, 17: 769-809.

Shi, Y. and Hamnett, C. (2002) The potential and prospect for global cities in China: In the context of the world system. Geoforum, 33: 121-135.

Stoughton, N.M., Wong, K.P. and Zechner, J. (2001) IPO’s and product quality. Journal of Business, 74: 375-408.

Stulz, R.M. (1999) Globalization, corporate finance, and the cost of capital. Journal of Applied Corporate Finance, 12: 8-25.

Tao, D. (2009) Shanghai is rising but does Hong Kong care enough? Hong Kong Journal, 16: 1-6. http://www.hkjournal.org/archive/2009_winter/1.htm [accessed July 2010]

Thrift, N.J. (1994) On the social and cultural determinants of international financial centres: The case of the City of London. In S. Corbridge, R.L. Martin, and N.J. Thrift (eds) Money, Power and Space, pp.327-355. Oxford: Blackwell.

Wang, Y. and Di Iorio, A. (2007) Are the China-related stock markets segmented with both world and regional stock markets? Journal of International Financial Markets, Institutions and Money, 17: 277-290.

Wang, D.T., Zhao, S.X.B. and Wang, D. (2007) Information hinterland - a base for financial centre development: The case of Beijing versus Shanghai in China. Tijdschrift voor Economische en Sociale Geografie, 98: 102-120.

Wild, D. (1997) Revels in a new rivalry. The Banker, 147 (July 1): 62-64.

Wong, Y.C. (2007) Shanghai: Another Hong Kong? Harvard International Review (webexclusive), http://hir.harvard.edu/index.php?page=article\&id=1479 [accessed July 2010].

Wójcik, D. (2009) Geography of stock markets. Geography Compass, 3/4: 1499-1514.

Wójcik, D. and Burger, C. (2010) Listing BRICs: Stock Issuers from Brazil, Russia, India, and China in New York, London, and Luxembourg. Economic Geography, 86: 275-296.

Yeo, S. (2003) The PRC qualified foreign institutional investors market. China Economic Review, 14: 443-450. 
Zhao, S.X.B. (2003) Spatial restructuring of financial centres in mainland China and Hong: A geography of finance perspective. Urban Affairs Review, 38: 535-571.

Zhao, S.X.B., Zhang, L. and Wang, D.T. (2004) Determining factors of the development of a national financial center: The case of China. Geoforum, 35: 577-592.

Zhang, X. and King, T-H. (2010) The decision to list abroad: The case of ADRs and foreign IPOs by Chinese companies. Journal of Multinational Financial Management, 20: 71-92. 
Table 1: Frequency of IPOs by exchange, per year and per industry.

Panel A

\begin{tabular}{lrrrr}
\hline & \multicolumn{3}{c}{ MARKET } & \\
YEAR & SSE & SZSE & HKEX & Total \\
\hline & & & & \\
1993 & 34 & 37 & 8 & 79 \\
1994 & 42 & 31 & 12 & 85 \\
1995 & 6 & 4 & 2 & 12 \\
1996 & 64 & 57 & 12 & 133 \\
1997 & 69 & 104 & 24 & 197 \\
1998 & 49 & 46 & 3 & 98 \\
1999 & 42 & 49 & 5 & 96 \\
2000 & 52 & 48 & 6 & 106 \\
2004 & 61 & 37 & 11 & 109 \\
2005 & 1 & 4 & 2 & 7 \\
2006 & 7 & 52 & 11 & 70 \\
2007 & 6 & 73 & 13 & 92 \\
& & & & \\
Total & 433 & 542 & 109 & 1084 \\
\hline
\end{tabular}

Panel B

\begin{tabular}{lrrrr}
\hline & \multicolumn{3}{c}{ MARKET } & \\
INDUSTRY & SSE & SZSE & HKEX & Total \\
\hline & & & & \\
Basic Materials & 79 & 112 & 15 & 206 \\
Consumer Goods & 90 & 114 & 9 & 213 \\
Consumer Services & 42 & 32 & 8 & 82 \\
Financials & 33 & 33 & 11 & 77 \\
Health Care & 37 & 36 & 5 & 78 \\
Industrials & 104 & 149 & 39 & 292 \\
Oil \& Gas & 3 & 8 & 4 & 15 \\
Technology & 24 & 42 & 13 & 79 \\
Utilities & 21 & 16 & 5 & 42 \\
& & & & \\
Total & 433 & 542 & 109 & 1084 \\
\hline
\end{tabular}


Table 2: Descriptive statistics ( $N=1084)$.

\begin{tabular}{|c|c|c|c|c|c|c|c|c|c|c|}
\hline Variable & Mean & S.d. & & 1 & 2 & 3 & 4 & 5 & 6 & 7 \\
\hline 1 Exchange & 1.70 & 0.64 & & & & & & & & \\
\hline 2 Total Assets & 18.52 & 1.16 & $0.192 *$ & & & & & & & \\
\hline 3 ROA & 7.05 & 6.68 & $0.097 *$ & $-0.181^{*}$ & & & & & & \\
\hline 4 Block & 0.80 & 0.40 & 0.002 & $-0.106^{*}$ & -0.029 & & & & & \\
\hline 5 Geographical Distance & 6.22 & 1.96 & $0.136 *$ & $-0.065^{*}$ & 0.028 & 0.049 & & & & \\
\hline 6 Beijing & 0.10 & 0.30 & $0.190 *$ & $0.154^{*}$ & 0.007 & $-0.161 *$ & $0.198 *$ & & & \\
\hline 7 Shanghai & 0.07 & 0.26 & $-0.163^{*}$ & $0.129 *$ & -0.020 & $-0.091 *$ & $-0.459 *$ & $-0.094 *$ & & \\
\hline 8 Shenzhen & 0.10 & 0.31 & $0.164 *$ & 0.026 & 0.026 & -0.004 & $-0.582 *$ & $-0.115^{*}$ & $-0.096 *$ & \\
\hline
\end{tabular}

${ }^{*} \mathrm{p}<0.05$ level (2-tailed) 
Table 3: MNL estimates of listing choice between SSE, SZSE and HKEX.

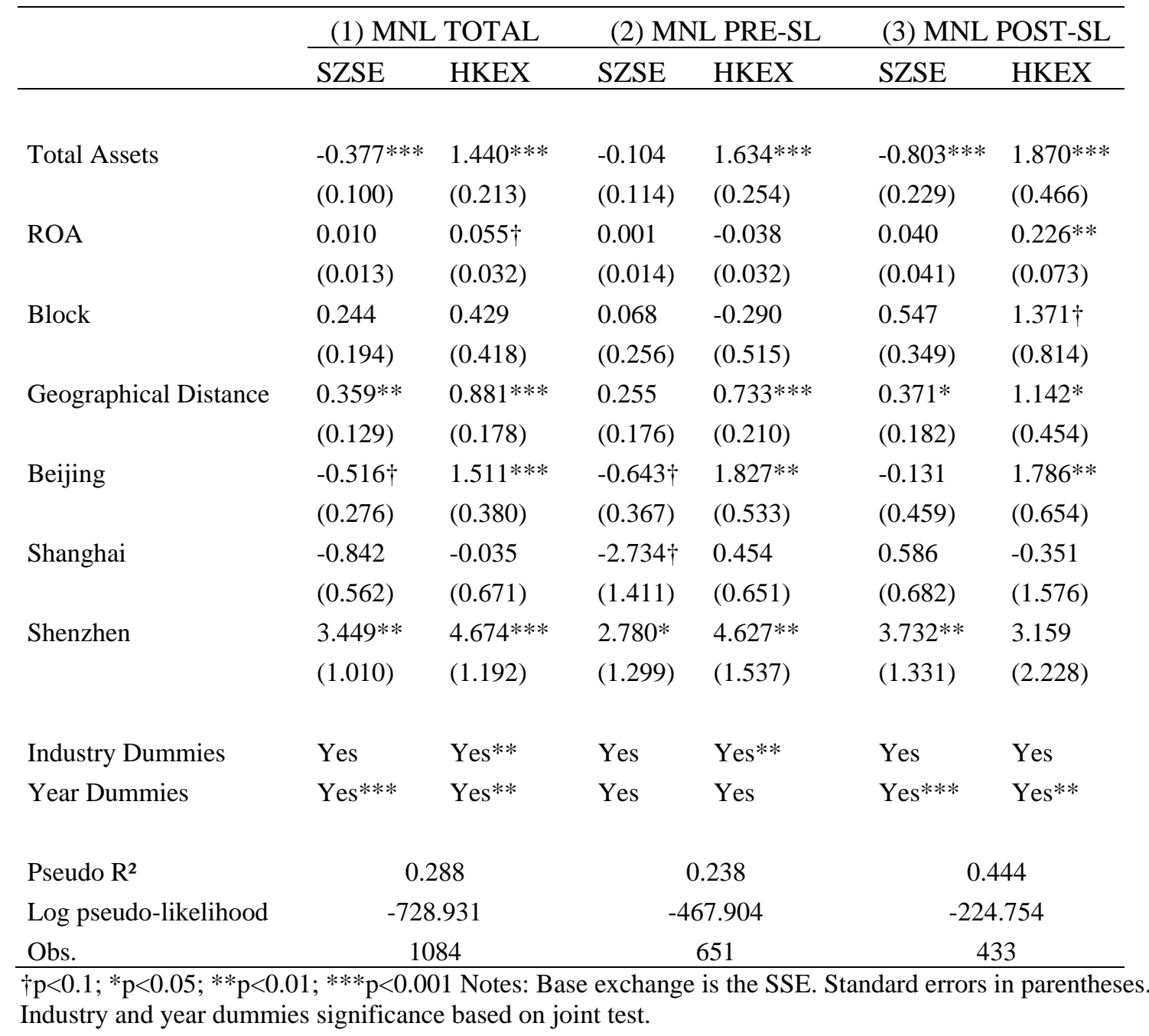


Table 4: Industry dummies of the MNL estimates.

\begin{tabular}{lllllll}
\hline & \multicolumn{2}{c}{$(4) \mathrm{MNL}$ TOTAL } & \multicolumn{2}{c}{ (5) MNL PRE-SL } & \multicolumn{2}{c}{ (6) MNL POST-SL } \\
\cline { 2 - 7 } & SZSE & HKEX & SZSE & HKEX & SZSE & HKEX \\
\hline \multirow{2}{*}{ Consumer Goods } & 0.044 & -0.161 & -0.010 & -0.624 & 0.182 & 1.257 \\
Consumer Services & $(0.227)$ & $(0.572)$ & $(0.287)$ & $(0.837)$ & $(0.394)$ & $(1.076)$ \\
& $-0.568 \dagger$ & 0.001 & -0.463 & -0.613 & -0.668 & 2.298 \\
Financials & $(0.323)$ & $(0.664)$ & $(0.359)$ & $(0.847)$ & $(0.789)$ & $(1.473)$ \\
& -0.115 & 0.088 & 0.154 & -0.032 & -1.764 & 0.928 \\
Health Care & $(0.359)$ & $(0.647)$ & $(0.393)$ & $(0.798)$ & $(1.076)$ & $(1.529)$ \\
Industrials & -0.219 & 0.962 & -0.287 & 0.595 & -0.227 & 2.611 \\
& $(0.305)$ & $(0.739)$ & $(0.391)$ & $(0.912)$ & $(0.490)$ & $(1.667)$ \\
Oil \& Gas & 0.028 & $1.182^{* *}$ & 0.071 & $1.606 * *$ & -0.291 & 1.172 \\
& $(0.221)$ & $(0.436)$ & $(0.275)$ & $(0.519)$ & $(0.379)$ & $(1.424)$ \\
Technology & 0.874 & $2.267 *$ & 1.075 & $2.134 \dagger$ & 0.648 & 3.627 \\
Utilities & $(0.671)$ & $(1.069)$ & $(0.803)$ & $(1.187)$ & $(0.984)$ & $(3.459)$ \\
& 0.132 & $1.638 *$ & 0.056 & 0.849 & 0.069 & $3.541^{*}$ \\
& $(0.326)$ & $(0.645)$ & $(0.425)$ & $(0.782)$ & $(0.569)$ & $(1.727)$ \\
& -0.299 & -0.786 & -0.461 & -0.711 & -0.042 & -0.030 \\
& $(0.383)$ & $(0.735)$ & $(0.471)$ & $(1.026)$ & $(0.597)$ & $(1.155)$ \\
\hline
\end{tabular}

$\dagger \mathrm{p}<0.1 ;{ }^{*} \mathrm{p}<0.05 ;{ }^{* *} \mathrm{p}<0.01 ;{ }^{* * *} \mathrm{p}<0.001$ Notes: Omitted industry dummy is Basic Materials. Base exchange is the SSE. Standard errors in parentheses. 
Table 5: MNL marginal effect estimates of listing choice between SSE, SZSE and HKEX.

\begin{tabular}{|c|c|c|c|c|c|c|c|c|c|}
\hline & \multicolumn{3}{|c|}{ (7) MEs TOTAL } & \multicolumn{3}{|c|}{ (8) MEs PRE-SL } & \multicolumn{3}{|c|}{ (9) MEs POST-SL } \\
\hline & SSE & SZSE & HKEX & SSE & SZSE & HKEX & SSE & SZSE & HKEX \\
\hline Total Assets & $\begin{array}{l}0.069 * * \\
(0.024)\end{array}$ & $\begin{array}{l}-0.117^{* * *} \\
(0.024)\end{array}$ & $\begin{array}{l}0.048^{* * *} \\
(0.008)\end{array}$ & $\begin{array}{l}0.004 \\
(0.028)\end{array}$ & $\begin{array}{l}-0.046 \\
(0.028)\end{array}$ & $\begin{array}{l}0.043^{* * *} \\
(0.010)\end{array}$ & $\begin{array}{l}0.164^{* *} \\
(0.054)\end{array}$ & $\begin{array}{l}-0.196 * * * \\
(0.056)\end{array}$ & $\begin{array}{l}0.032 * \\
(0.015)\end{array}$ \\
\hline ROA & $\begin{array}{l}-0.003 \\
(0.003)\end{array}$ & $\begin{array}{l}0.002 \\
(0.003)\end{array}$ & $\begin{array}{l}0.001 \dagger \\
(0.001)\end{array}$ & $\begin{array}{l}0.000 \\
(0.003)\end{array}$ & $\begin{array}{l}0.001 \\
(0.003)\end{array}$ & $\begin{array}{l}-0.001 \\
(0.001)\end{array}$ & $\begin{array}{l}-0.010 \\
(0.009)\end{array}$ & $\begin{array}{l}0.007 \\
(0.009)\end{array}$ & $\begin{array}{l}0.003 \dagger \\
(0.002)\end{array}$ \\
\hline Block & $\begin{array}{l}-0.062 \\
(0.047)\end{array}$ & $\begin{array}{l}0.054 \\
(0.047)\end{array}$ & $\begin{array}{l}0.008 \\
(0.010)\end{array}$ & $\begin{array}{l}-0.012 \\
(0.062)\end{array}$ & $\begin{array}{l}0.021 \\
(0.062)\end{array}$ & $\begin{array}{l}-0.009 \\
(0.016)\end{array}$ & $\begin{array}{l}-0.128 \\
(0.081)\end{array}$ & $\begin{array}{l}0.117 \\
(0.081)\end{array}$ & $\begin{array}{l}0.011 \\
(0.010)\end{array}$ \\
\hline Geographical Distance & $\begin{array}{l}-0.093^{* *} \\
(0.030)\end{array}$ & $\begin{array}{l}0.074^{*} \\
(0.029)\end{array}$ & $\begin{array}{l}0.019 * * * \\
(0.005)\end{array}$ & $\begin{array}{l}-0.070 \\
(0.044)\end{array}$ & $\begin{array}{l}0.054 \\
(0.042)\end{array}$ & $\begin{array}{l}0.015^{* *} \\
(0.005)\end{array}$ & $\begin{array}{l}-0.084 * \\
(0.039)\end{array}$ & $\begin{array}{l}0.073 \dagger \\
(0.039)\end{array}$ & $\begin{array}{l}0.012 * \\
(0.005)\end{array}$ \\
\hline Beijing & $\begin{array}{l}0.067 \\
(0.065)\end{array}$ & $\begin{array}{l}-0.174 * * \\
(0.063)\end{array}$ & $\begin{array}{l}0.107 * \\
(0.044)\end{array}$ & $\begin{array}{l}0.067 \\
(0.084)\end{array}$ & $\begin{array}{l}-0.199 * * \\
(0.075)\end{array}$ & $\begin{array}{l}0.132 * \\
(0.056)\end{array}$ & $\begin{array}{l}0.010 \\
(0.098)\end{array}$ & $\begin{array}{l}-0.065 \\
(0.108)\end{array}$ & $\begin{array}{l}0.055 \\
(0.055)\end{array}$ \\
\hline Shanghai & $\begin{array}{l}0.194 \\
(0.130)\end{array}$ & $\begin{array}{l}-0.206 \\
(0.127)\end{array}$ & $\begin{array}{l}0.013 \\
(0.025)\end{array}$ & $\begin{array}{l}0.422^{* * *} \\
(0.101)\end{array}$ & $\begin{array}{l}-0.468^{* * *} \\
(0.093)\end{array}$ & $\begin{array}{l}0.047 \\
(0.041)\end{array}$ & $\begin{array}{l}-0.113 \\
(0.118)\end{array}$ & $\begin{array}{l}0.120 \\
(0.120)\end{array}$ & $\begin{array}{l}-0.008 \\
(0.012)\end{array}$ \\
\hline Shenzhen & $\begin{array}{l}-0.472 * * * \\
(0.045)\end{array}$ & $\begin{array}{l}0.361 * * * \\
(0.060)\end{array}$ & $\begin{array}{l}0.111^{*} \\
(0.053) \\
\end{array}$ & $\begin{array}{l}-0.507^{* * *} \\
(0.092)\end{array}$ & $\begin{array}{l}0.320^{* *} \\
(0.113)\end{array}$ & $\begin{array}{l}0.188 \dagger \\
(0.106) \\
\end{array}$ & $\begin{array}{l}-0.393^{* * *} \\
(0.053)\end{array}$ & $\begin{array}{l}0.393 * * * \\
(0.057)\end{array}$ & $\begin{array}{l}-0.001 \\
(0.019) \\
\end{array}$ \\
\hline
\end{tabular}




\section{Appendix: Additional results of the robustness checks}

Table 6: MNP estimates of listing choice between SSE, SZSE and HKEX.

\begin{tabular}{|c|c|c|c|c|c|c|}
\hline & \multicolumn{2}{|c|}{ (10) MNP TOTAL } & \multicolumn{2}{|c|}{ (11) MNP PRE-SL } & \multicolumn{2}{|c|}{ (12) MNP POST-SL } \\
\hline & SZSE & HKEX & SZSE & HKEX & SZSE & HKEX \\
\hline Total Assets & $\begin{array}{l}-0.332^{* * *} \\
(0.078)\end{array}$ & $\begin{array}{l}0.882 * * * \\
(0.124)\end{array}$ & $\begin{array}{l}-0.090 \\
(0.095)\end{array}$ & $\begin{array}{l}1.128 * * * \\
(0.162)\end{array}$ & $\begin{array}{l}-0.631^{* * *} \\
(0.177)\end{array}$ & $\begin{array}{l}1.204^{* * *} \\
(0.254)\end{array}$ \\
\hline ROA & $\begin{array}{l}0.007 \\
(0.010)\end{array}$ & $\begin{array}{l}0.025 \\
(0.023)\end{array}$ & $\begin{array}{l}0.000 \\
(0.012)\end{array}$ & $\begin{array}{l}-0.024 \\
(0.020)\end{array}$ & $\begin{array}{l}0.023 \\
(0.028)\end{array}$ & $\begin{array}{l}0.153^{* *} \\
(0.044)\end{array}$ \\
\hline Block & $\begin{array}{l}0.223 \\
(0.160)\end{array}$ & $\begin{array}{l}0.187 \\
(0.262)\end{array}$ & $\begin{array}{l}0.080 \\
(0.213)\end{array}$ & $\begin{array}{l}-0.321 \\
(0.322)\end{array}$ & $\begin{array}{l}0.485 \dagger \\
(0.269)\end{array}$ & $\begin{array}{l}1.057 * \\
(0.483)\end{array}$ \\
\hline Geographical Distance & $\begin{array}{l}0.195^{* *} \\
(0.066)\end{array}$ & $\begin{array}{l}0.485 * * * \\
(0.089)\end{array}$ & $\begin{array}{l}0.117 \\
(0.088)\end{array}$ & $\begin{array}{l}0.426 * * * \\
(0.097)\end{array}$ & $\begin{array}{l}0.239 * \\
(0.116)\end{array}$ & $\begin{array}{l}0.763 * * \\
(0.258)\end{array}$ \\
\hline Beijing & $\begin{array}{l}-0.389 \dagger \\
(0.224)\end{array}$ & $\begin{array}{l}1.233 * * * \\
(0.263)\end{array}$ & $\begin{array}{l}-0.506 \dagger \\
(0.295)\end{array}$ & $\begin{array}{l}1.261^{* * *} \\
(0.359)\end{array}$ & $\begin{array}{l}0.018 \\
(0.369)\end{array}$ & $\begin{array}{l}1.444^{* *} \\
(0.444)\end{array}$ \\
\hline Shanghai & $\begin{array}{l}-1.022 * * \\
(0.356)\end{array}$ & $\begin{array}{l}-0.143 \\
(0.442)\end{array}$ & $\begin{array}{l}-2.353^{* *} \\
(0.743)\end{array}$ & $\begin{array}{l}-0.140 \\
(0.465)\end{array}$ & $\begin{array}{l}0.330 \\
(0.522)\end{array}$ & $\begin{array}{l}-0.075 \\
(0.951)\end{array}$ \\
\hline Shenzhen & $\begin{array}{l}2.035^{* * *} \\
(0.444)\end{array}$ & $\begin{array}{l}2.640 * * * \\
(0.505)\end{array}$ & $\begin{array}{l}1.597 * * \\
(0.553)\end{array}$ & $\begin{array}{l}2.768 * * * \\
(0.632)\end{array}$ & $\begin{array}{l}2.591 * * * \\
(0.741)\end{array}$ & $\begin{array}{l}1.973 \dagger \\
(1.079)\end{array}$ \\
\hline Industry Dummies & Yes & Yes** & Yes & Yes** & Yes & Yes \\
\hline Year Dummies & Yes*** & Yes*** & Yes & Yes & Yes*** & Yes*** \\
\hline Log pseudo-likelihood & -73 & 476 & & 1.777 & -22 & 070 \\
\hline Obs. & & 84 & & 51 & & \\
\hline
\end{tabular}


Table 7: Outlier analysis: MNL estimates of listing choice between SSE, SZSE and HKEX.

\begin{tabular}{|c|c|c|c|c|c|c|}
\hline & \multicolumn{2}{|c|}{ (13) MNL TOTAL } & \multicolumn{2}{|c|}{ (14) MNL PRE-SL } & \multicolumn{2}{|c|}{ (15) MNL POST-SL } \\
\hline & SZSE & HKEX & SZSE & HKEX & SZSE & HKEX \\
\hline Total Assets & $\begin{array}{l}-0.329 * * \\
(0.101)\end{array}$ & $\begin{array}{l}1.618^{* * *} \\
(0.226)\end{array}$ & $\begin{array}{l}-0.104 \\
(0.114)\end{array}$ & $\begin{array}{l}1.628 * * * \\
(0.253)\end{array}$ & $\begin{array}{l}-0.712^{* *} \\
(0.244)\end{array}$ & $\begin{array}{l}3.234 * * * \\
(0.634)\end{array}$ \\
\hline ROA & $\begin{array}{l}0.010 \\
(0.013)\end{array}$ & $\begin{array}{l}0.054 \dagger \\
(0.032)\end{array}$ & $\begin{array}{l}0.001 \\
(0.014)\end{array}$ & $\begin{array}{l}-0.043 \\
(0.034)\end{array}$ & $\begin{array}{l}0.048 \\
(0.044)\end{array}$ & $\begin{array}{l}0.321^{* * *} \\
(0.088)\end{array}$ \\
\hline Block & $\begin{array}{l}0.253 \\
(0.195)\end{array}$ & $\begin{array}{l}0.485 \\
(0.454)\end{array}$ & $\begin{array}{l}0.069 \\
(0.256)\end{array}$ & $\begin{array}{l}-0.265 \\
(0.515)\end{array}$ & $\begin{array}{l}0.579 \\
(0.353)\end{array}$ & $\begin{array}{l}1.785 \\
(1.404)\end{array}$ \\
\hline Geographical Distance & $\begin{array}{l}0.355^{* *} \\
(0.132)\end{array}$ & $\begin{array}{l}0.896 * * * \\
(0.182)\end{array}$ & $\begin{array}{l}0.255 \\
(0.176)\end{array}$ & $\begin{array}{l}0.729 * * \\
(0.210)\end{array}$ & $\begin{array}{l}0.369 \dagger \\
(0.190)\end{array}$ & $\begin{array}{l}2.395 \dagger \\
(1.256)\end{array}$ \\
\hline Beijing & $\begin{array}{l}-0.513 \dagger \\
(0.275)\end{array}$ & $\begin{array}{l}1.498 * * * \\
(0.397)\end{array}$ & $\begin{array}{l}-0.642 \dagger \\
(0.366)\end{array}$ & $\begin{array}{l}1.821^{* *} \\
(0.529)\end{array}$ & $\begin{array}{l}-0.129 \\
(0.463)\end{array}$ & $\begin{array}{l}1.694 * \\
(0.762)\end{array}$ \\
\hline Shanghai & $\begin{array}{l}-0.860 \\
(0.591)\end{array}$ & $\begin{array}{l}0.037 \\
(0.619)\end{array}$ & $\begin{array}{l}-2.734 \dagger \\
(1.410)\end{array}$ & $\begin{array}{l}0.463 \\
(0.650)\end{array}$ & $\begin{array}{l}0.515 \\
(0.720)\end{array}$ & $\begin{array}{l}0.398 \\
(1.229)\end{array}$ \\
\hline Shenzhen & $\begin{array}{l}3.411^{* *} \\
(1.024)\end{array}$ & $\begin{array}{l}4.681^{* * *} \\
(1.225)\end{array}$ & $\begin{array}{l}2.780 * \\
(1.299)\end{array}$ & $\begin{array}{l}4.629 * * \\
(1.534)\end{array}$ & $\begin{array}{l}3.712 * * \\
(1.372)\end{array}$ & $\begin{array}{l}4.515 \\
(3.706)\end{array}$ \\
\hline Industry Dummies & Yes & Yes*** & Yes & Yes** & Yes & Yes*** \\
\hline Year Dummies & Yes*** & Yes*** & Yes & Yes & Yes*** & Yes** \\
\hline Pseudo R² & & 81 & & 0.236 & & 452 \\
\hline Log pseudo-likelihood & & .333 & & 467.681 & & 3.375 \\
\hline Obs. & & 68 & & 650 & & 18 \\
\hline
\end{tabular}

$\uparrow \mathrm{p}<0.1 ;{ }^{*} \mathrm{p}<0.05 ;{ }^{* *} \mathrm{p}<0.01 ;{ }^{* * *} \mathrm{p}<0.001$ Notes: Base exchange is the SSE. Standard errors in parentheses. Industry and year dummies significance based on joint test. 


\section{Publications in the ERIM Report Series Research* in Management}

\section{ERIM Research Program: "Organizing for Performance"}

2010

Investigating the Perceptions of Credit Constraints in the European Union

Erik Canton, Isabel Grilo, Josefa Monteagudo, and Peter van der Zwan

ERS-2010-001-ORG

http://hdl.handle.net/1765/17699

Two Lighthouses to Navigate: Effects of Ideal and Counter-Ideal Values on Follower Identification and Satisfaction with their Leaders

Niels van Quaquebeke, Rudolf Kerschreiter, Alice E. Buxton, and Rolf van Dick

ERS-2010-003-ORG

http://hdl.handle.net/1765/17702

Genome-wide Association Studies and the Genetics of Entrepreneurship

Matthijs J.H.M. van der Loos, Philipp D. Koellinger, Patrick J.F. Groenen, and A. Roy Thurik

ERS-2010-004-ORG

http://hdl.handle.net/1765/17757

How embodied cognitions affect judgments: Height-related attribution bias in football foul calls

Niels van Quaquebeke and Steffen R. Giessner

ERS-2010-006-ORG

http://hdl.handle.net/1765/17827

Flexible Labor and Innovation Performance: Evidence from Longitudinal Firm-Level Data

Haibo Zhou, Ronald Dekker, and Alfred Kleinknecht

ERS-2010-007-ORG

http://hdl.handle.net/1765/18037

The Influence of Installed Technologies on Future Adoption Decisions: Empirical Evidence from E-Business

Philipp Koellinger and Christian Schade

ERS-2010-012-ORG

http://hdl.handle.net/1765/18463

Seeds of Regional Structural Change: The Role of Entrepreneurs and Expanding Firms in Shaping Local Path Dependencies

Frank Neffke and Martin Henning

ERS-2010-014-ORG

http://hdl.handle.net/1765/19207

Determinants of Contractual Completeness in Franchising

George Hendrikse and Josef Windsperger

ERS-2010-017-ORG

http://hdl.handle.net/1765/19424

Agglomeration and New Establishment Survival: A Mixed Hierarchical and Cross-Classified Model

Martijn J. Burger, Frank G. van Oort, and Otto Raspe

ERS-2010-018-ORG

http://hdl.handle.net/1765/19519

Corporate Social Responsibility in Large Family and Founder Firms

Joern Block and Marcus Wagner

ERS-2010-027-ORG

http://hdl.handle.net/1765/20273 
The Social Capital of Venture Capitalists and Its Impact on the Funding of Start-Up Firms

Oliver Alexy, Joern H. Block, Philipp Sander, and Anne L.J. Ter Wal

ERS-2010-028-ORG

http://hdl.handle.net/1765/20274

House Prices, Bubbles and City Size

Mark J.P.M. Thissen, Martijn J. Burger, and Frank G. van Oort

ERS-2010-030-ORG

http://hdl.handle.net/1765/20380

The Geography of Equity Listing and Financial Centre Competition in Mainland China and Hong Kong

Bas Karreman, and Bert van der Knaap

ERS-2010-033-ORG

http://hdl.handle.net/1765/20447

* A complete overview of the ERIM Report Series Research in Management: https://ep.eur.nl/handle/1765/1

ERIM Research Programs:

LIS Business Processes, Logistics and Information Systems

ORG Organizing for Performance

MKT Marketing

F\&A Finance and Accounting

STR Strategy and Entrepreneurship 